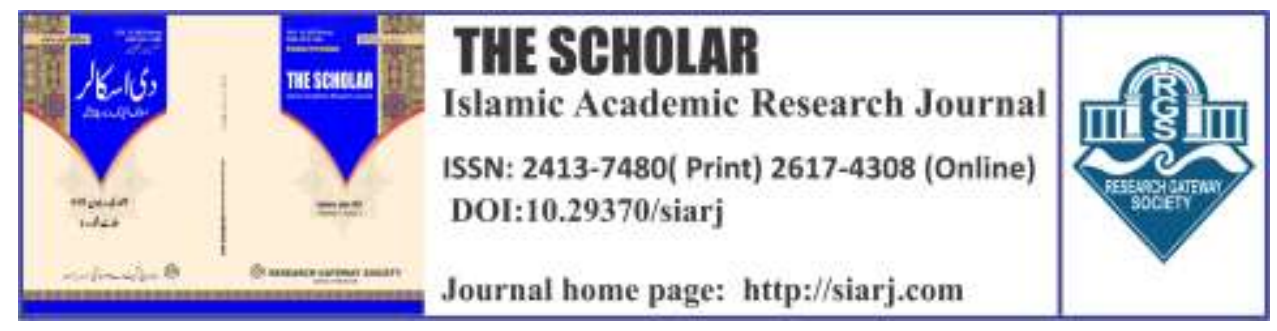

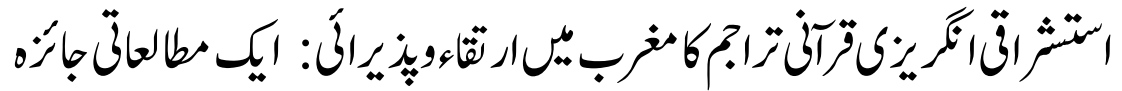

\title{
A REVIEW OF EVOLUTION OF ORIENTAL ENGLISH TRANSLATIONS OF QURAN IN WEST
}

\section{Afshan Noureen}

Ph.D. Scholar, Islamic And Arabic

Department, University of Sargodha.

Email: afshann6@gmail.com

\section{ORCID ID:}

https://orcid.org/0000-0002-5895-5286
2. Farhat Naseem Alvi

Assistant professor, Islamic And Arabic Department, University of Sargodha.

Email: farhat.naseem@uos.edu.pk

\section{ORCID |D:}

https://orcid.org/0000-0001-9565-7889

\section{To cite this article:}

Noureen, Afshan, and Farhat Naseem Alvi. "URDU-A REVIEW OF EVOLUTION OF ORIENTAL ENGLISH TRANSLATIONS OF QURAN IN WEST." The Scholar-Islamic Academic Research Journal 7, No. 2 (December 24, 2021).

To link to this article: https://doi.org/10.29370/siarj/issue13urduar5

Journal

Publisher

DOI:

URL:

License:

Journal homepage

Published online:
The Scholar Islamic Academic Research Journal Vol. 7, No. 2 || July -December 2021 || P. 75-95 Research Gateway Society 10.29370/siarj/issue13urduar5 https://doi.org/10.29370/siarj/ issue13urduar5 Copyright c 2017 NC-SA 4.0 wWw.siarj.com 2021-12-24
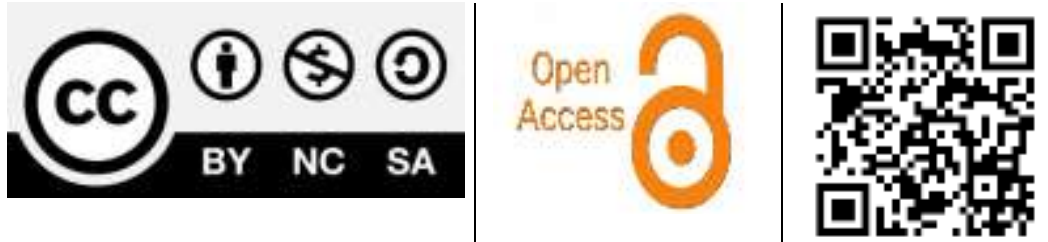


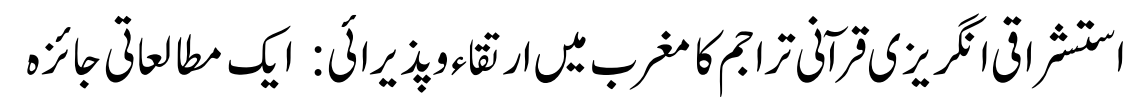 A REVIEW OF EVOLUTION OF ORIENTAL ENGLISH TRANSLATIONS OF QURAN IN WEST
}

\author{
Afshan Noureen, Farhat Naseem Alvi
}

\section{ABSTRACT:}

The historical evolution of English translations of Holy Quran is a phenomenon which gradually emerged over centuries. There have been seven different complete Quran translations since sixteenth century by Non-Muslim Orientalists. A brief review of Evolution of Oriental English Translations of Quran has been presented in this research study. All of these translations are mistaken, astray, and full of errors and have been written with prejudice against Islamic teachings and Prophet Muhammad (PBUH). Most of these orientalist translators having (Christian) religious background tried their level best to raise doubts regarding revelation, compilation and preservation of Quran. The hostility and prejudice of these English translators declined over the years and they have gradually learned to use reasoning and logic to defy Quran and teachings of Prophet Muhammad. There were several supporting factors behind successful evolution of these English Oriental translations including publishing companies, government institutions, religious scholars, controversial arguments, dramatic suppositions and the universities in the west. A few modern day Quran translations also appeared on the horizon of field of Oriental studies; however they continued the tradition of their ancestors regarding undermining the teachings of Quran intentionally or unintentionally with their clearly evident prejudice. Some of the reasons for evolution and successful emergence of these English Quran 
translations have been identified during the course of this research and are briefly discussed.

KEYWORDS: Orientalism, English Quranic Translations, Evolution, dramatic suppositions, controversial arguments.

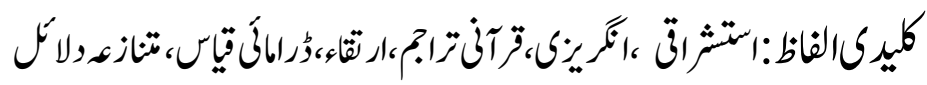

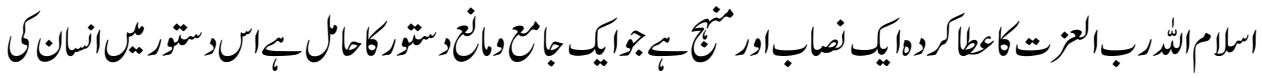

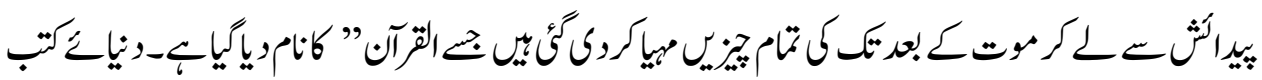

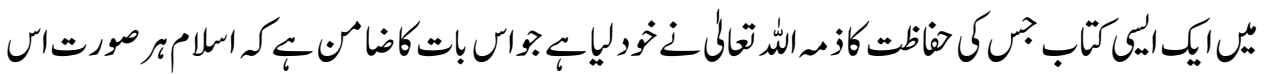

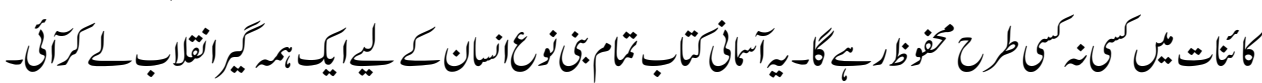

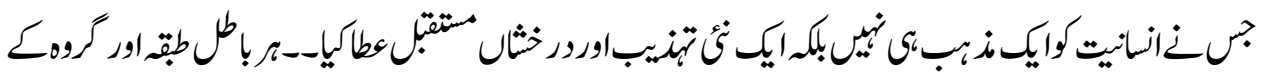

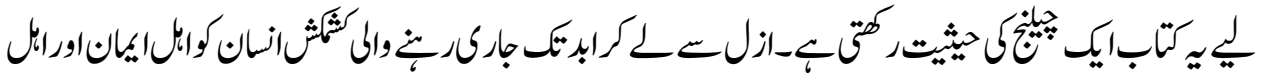

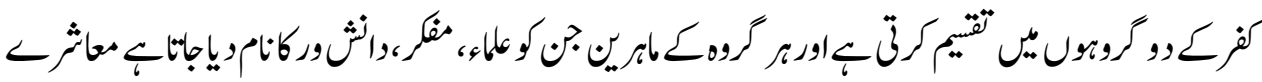

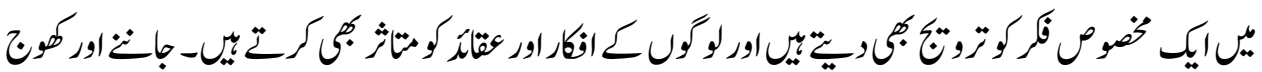

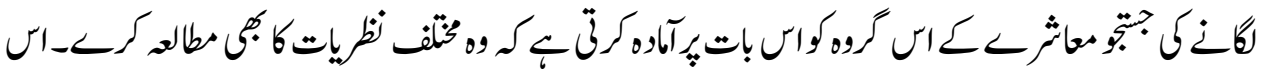

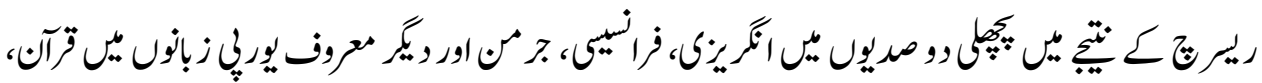

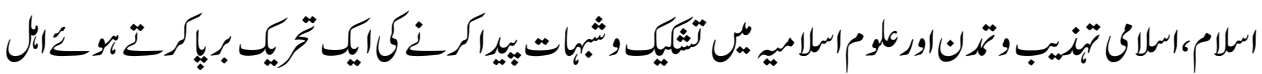

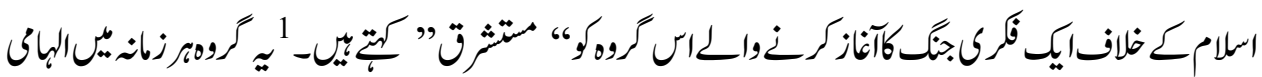

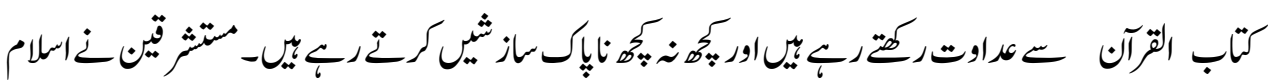

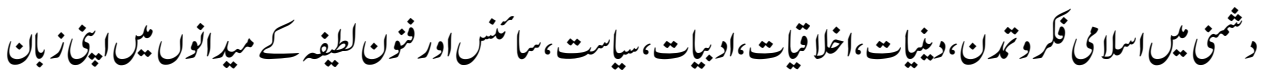

Shirf ud din Islahi,Dr, Islam Aur Mustashreqeen, Azam Garh,Dar-UlMussnifeen, Sept 1982, Vol.1,P.165. 


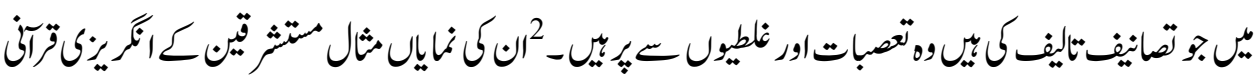

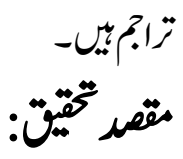

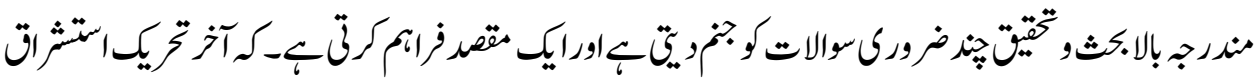

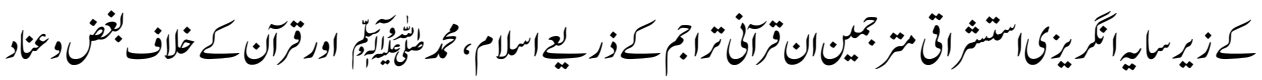

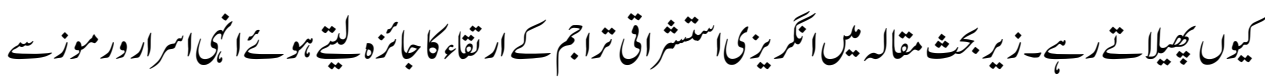

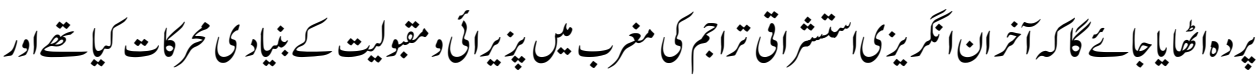

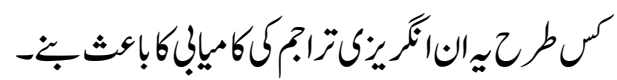

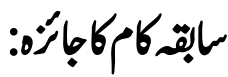

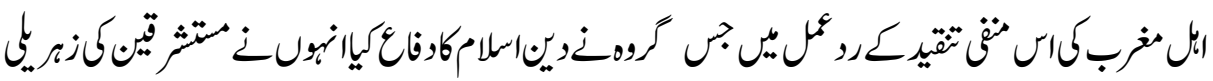

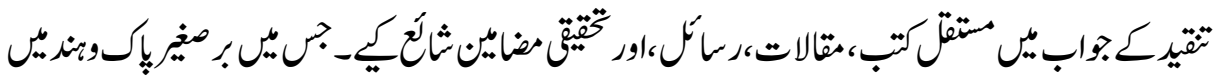

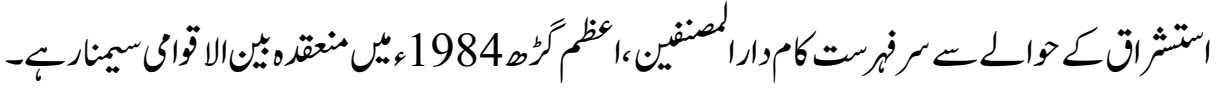

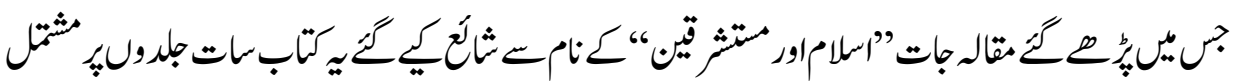

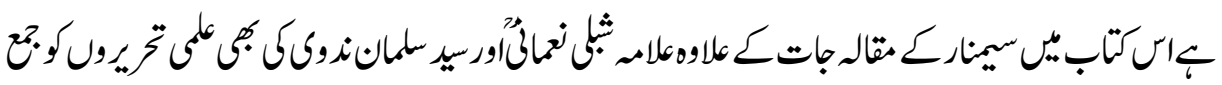

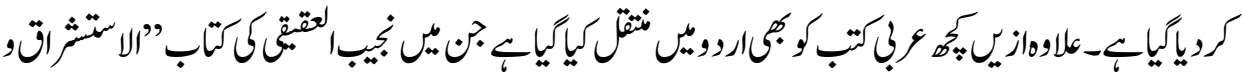

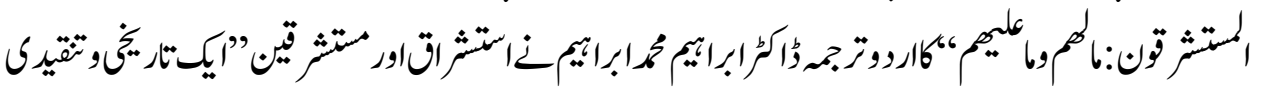

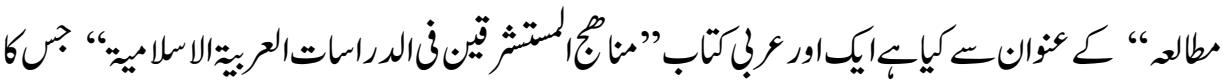

2 Nadwi, Abu-Al-Hassan, Muslim Mumalik main Islamyat aur Maghrabiat ki kashmakush, Majlis Nashrayat, Karachi,1976, p.256.

3 (Muhammad Khalifa is from Cairo Egypt and is a very well-known scholar. He has completed his P.H.D from Toronto University Canada in Electrical Engineering. When he read Oriental Scholars false literature about Islam in Canada, he decided to respond to it with his literary work. He worked hard and wrote a book after ten years continuous dedication and hard work named "Sublime Quran and Orientalism" with the purpose to spread true message of Islam.) 


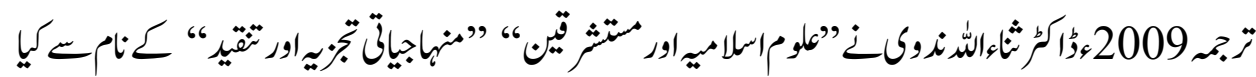

Orientalism Western Conceptions of the COrient,

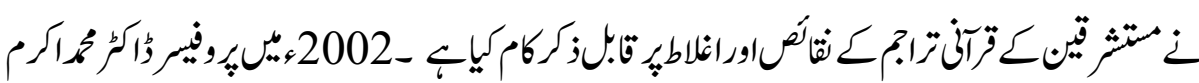

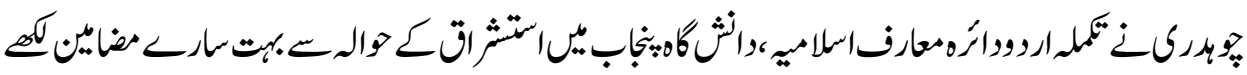

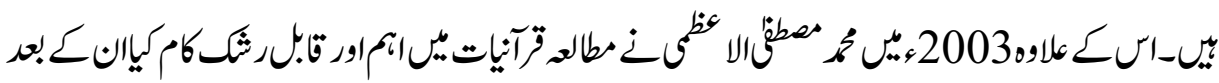

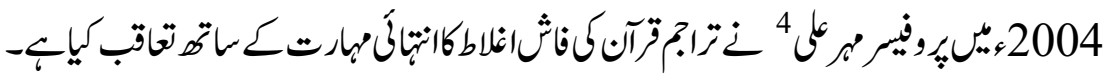

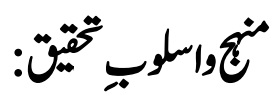

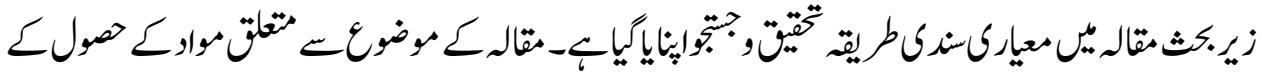

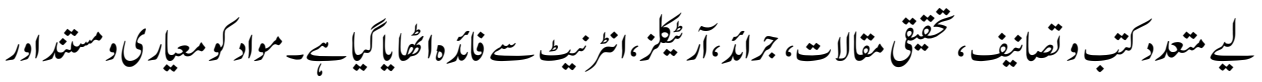

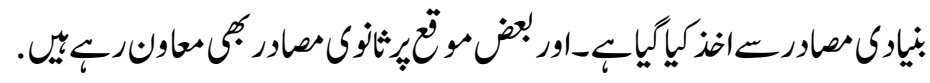

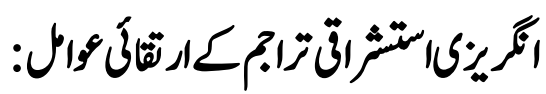

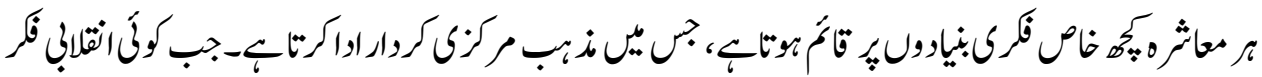

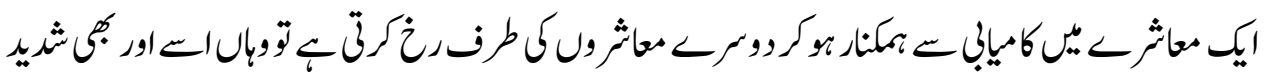

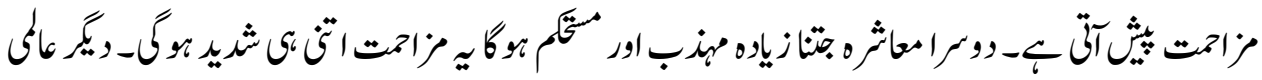

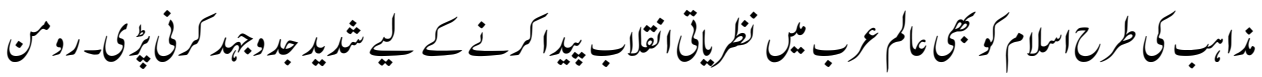

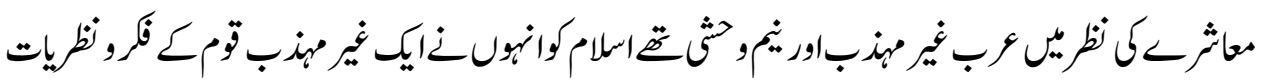

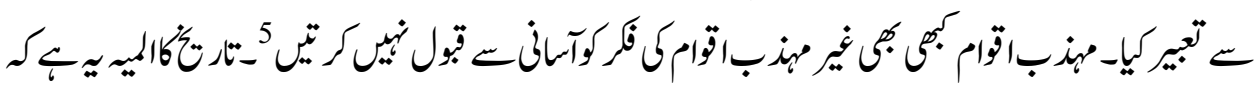

\footnotetext{
${ }^{4}$ Mohammed Mohar Ali, The Koran and Orientalists Jamyiat Ihyaa Minhajj ul Sunnah 2004(Mohammad Mohar Ali met renowned Oriental Scholars of $19^{\text {th }}$ and $20^{\text {th }}$ Century and rejected their false literal claims with strong and well established arguments.)

${ }^{5}$ Jones A.H.M, The Decline of the Ancient world, Longman Singapore Publishers Ltd, 1966, p.10.
} 


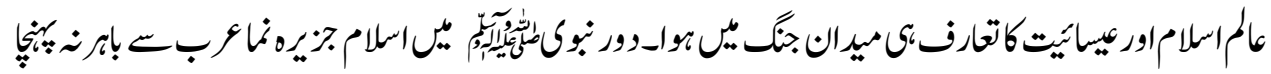

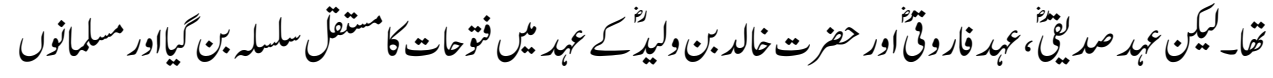

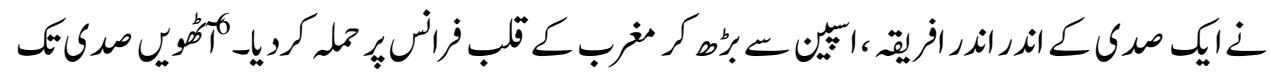

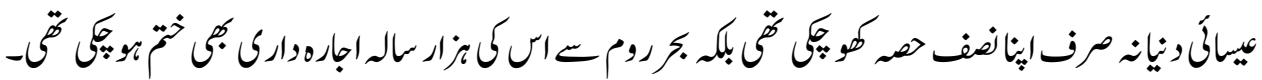

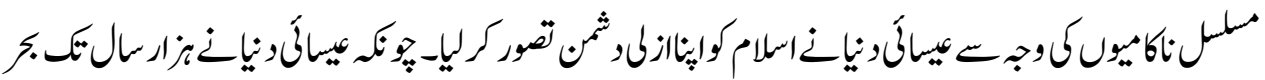

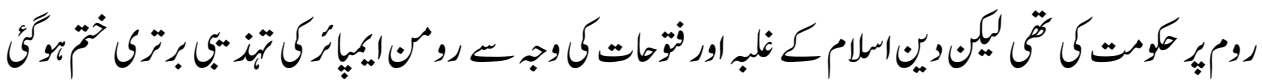

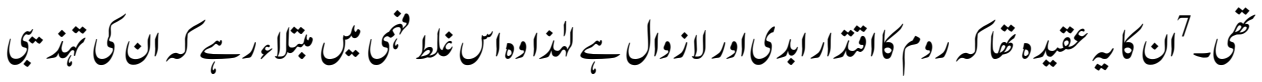

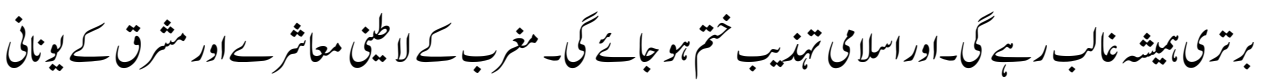

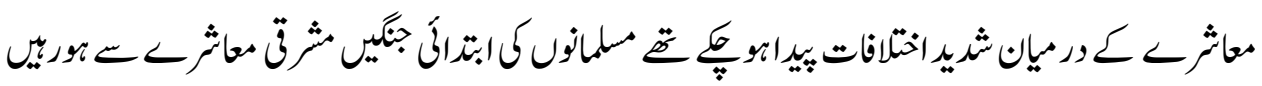

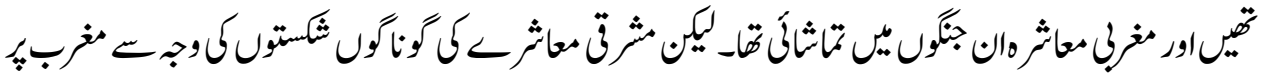

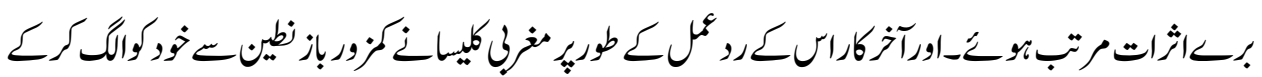

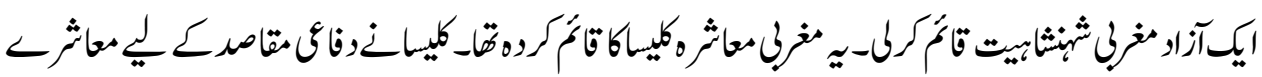

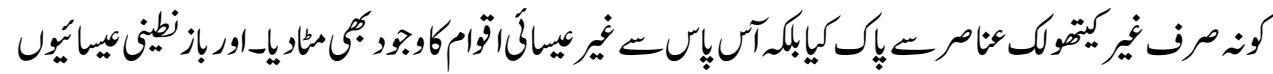

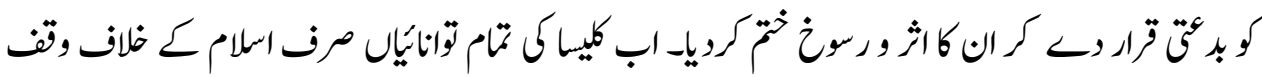

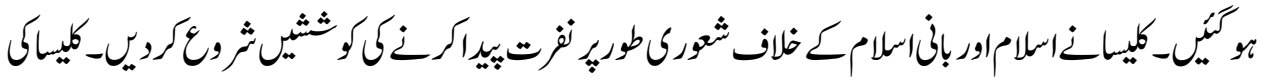

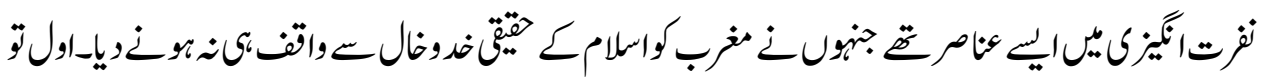

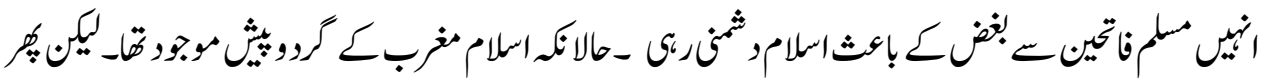

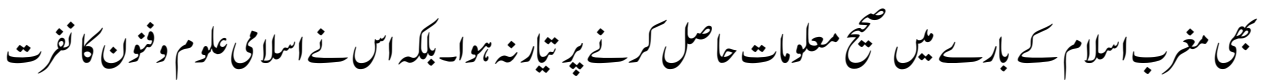

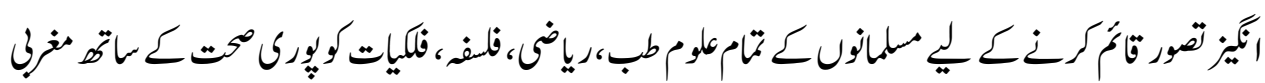

${ }^{6}$ Salma Khadra, Manuela Marin, The Legacy of Muslim Spain, E.J. Brill, New York, $2^{\text {nd }}$ Edt., 1994, p.97

${ }^{7}$ Fuller, J.F.C, The Decisive Battles of the western world, Great Britain, 1954, p. 241

8 Abdul Qadir Jillani, Dr, Islam, Pyghamber-e-Islam Aur Mustashreqeen-eMaghrib ka Andaz-e-Fikar,Kitab Siray Lahore,2010,p.92. 


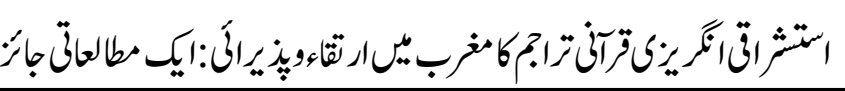

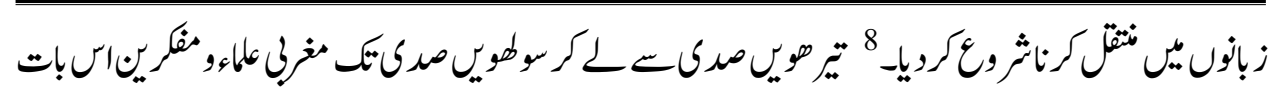

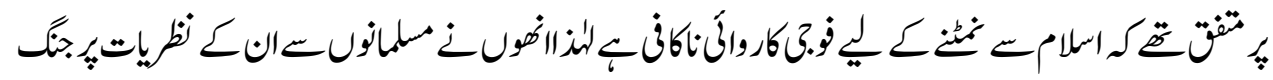

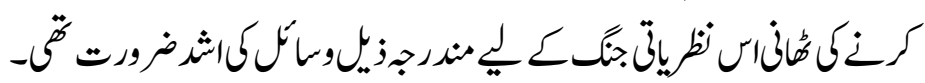

(i)

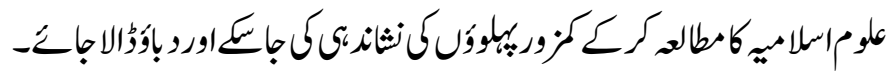

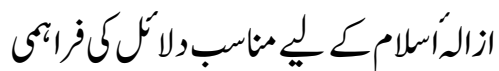

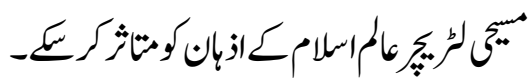

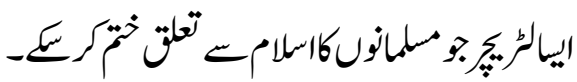

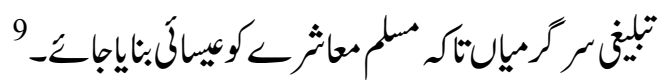

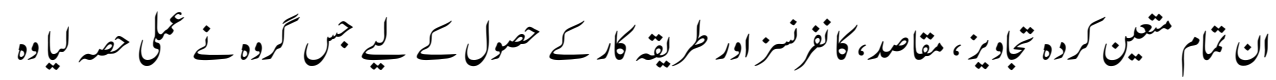

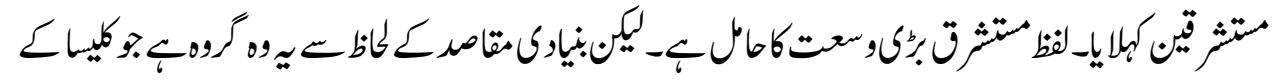

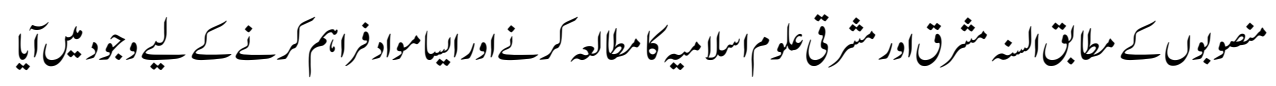

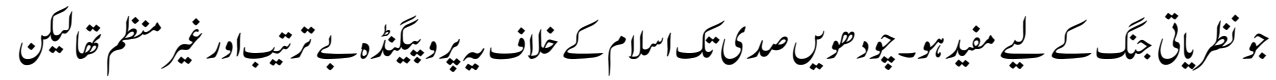

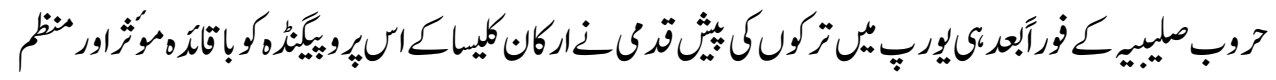

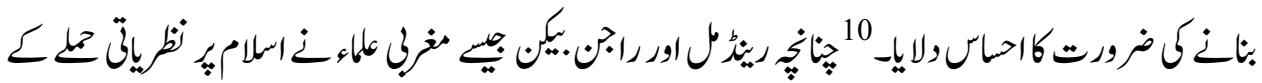

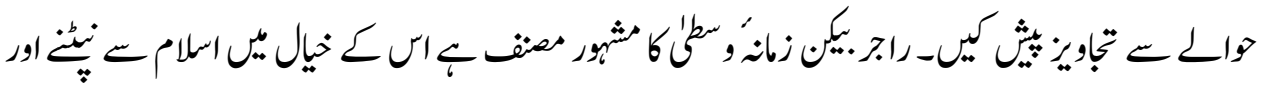

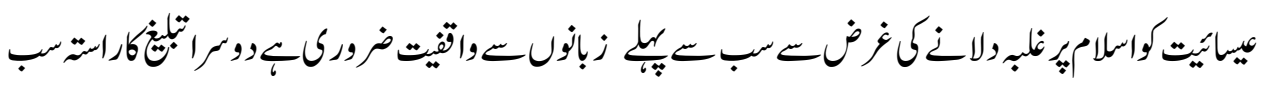

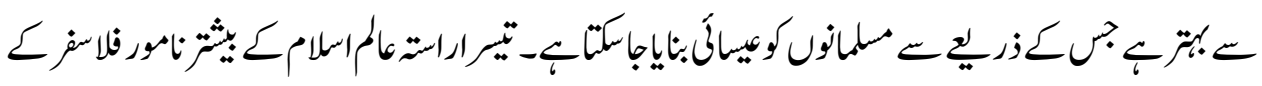

${ }^{9}$ Armoud Vorlijik, Richard Van Leeuwen, Arabic Studies in the Nether Lands: A Short history in parfaits, 1580-1950, Brill, Leiden Boston, 2014, p.12

${ }^{10}$ Marion L. Kuntz, Guillaume Postel, Prophet of the Restitution of All Things his life and thought, springer science business media, B.V, 1981, Preface (Guillaume Postel published the first Arabic grammar for European Scholars containing a printed repudiation of the opening surah of Koran) 


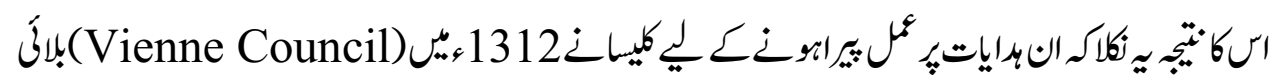

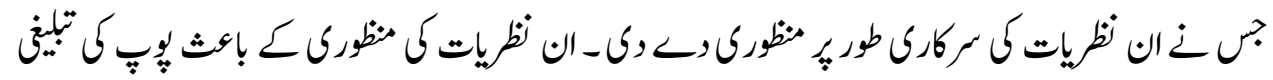

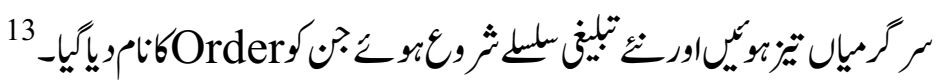

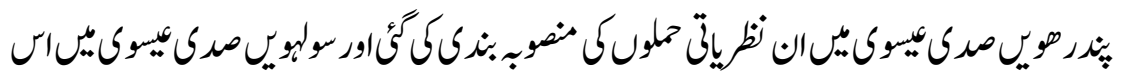

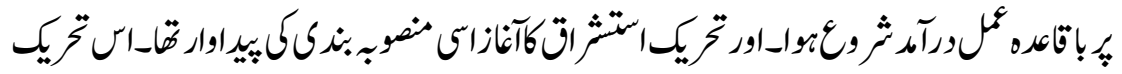

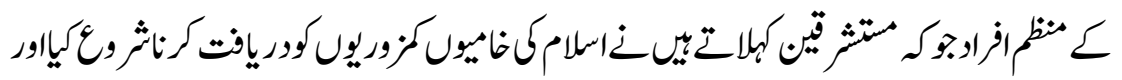

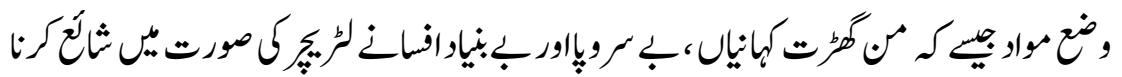

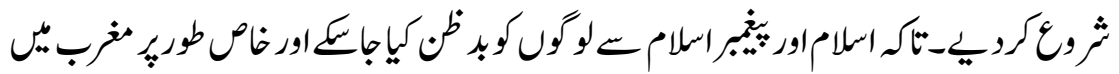

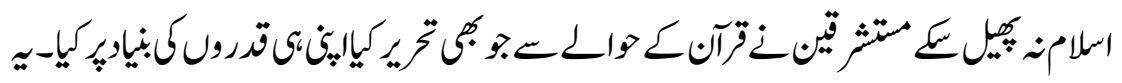

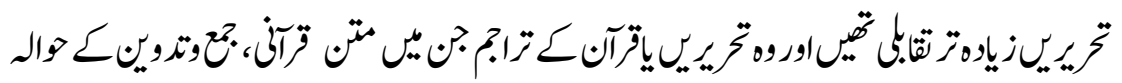

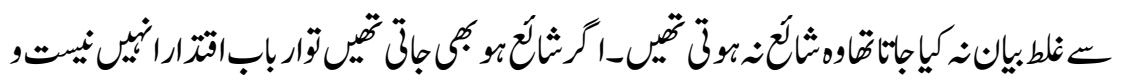

11 Tomaz Mastank, Crusading Peace: Christendom, the Muslim World, and western political order university of California Press, London 2002, pp.196$204,216$.

12 Abdul Qadir Jillani, Dr, Islam, Pyghamber-e-Islam Aur Mustashreqeen-eMaghrib ka Andaz-e-Fikar,Kitab Siray Lahore,2010,p.142-143.

${ }^{13}$ Tomaz Mastanak, Crusading Peace: Christendom, The Muslim World, and Western Political order University of California Press, London 1916, pp.204-216 


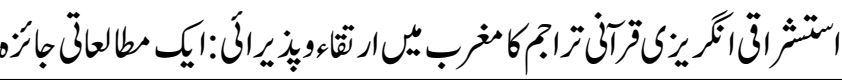

نابوركيّت

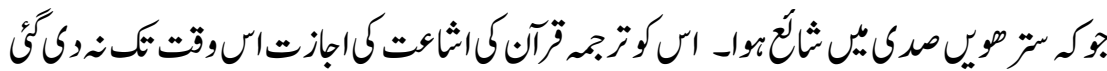

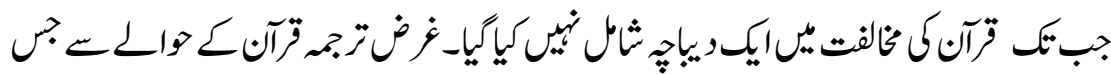

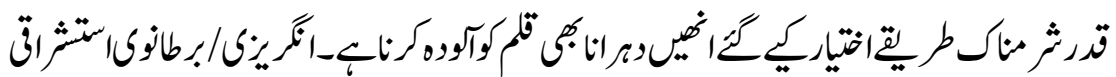

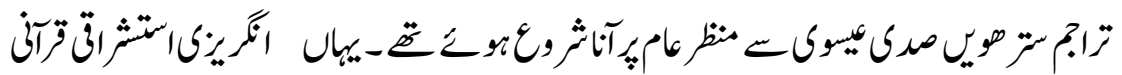

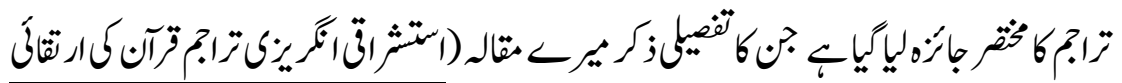

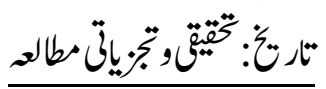

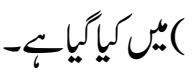

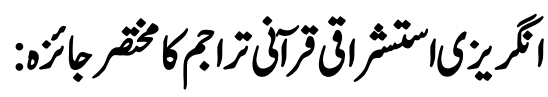

كtralexander Ross

6Alexander Ross

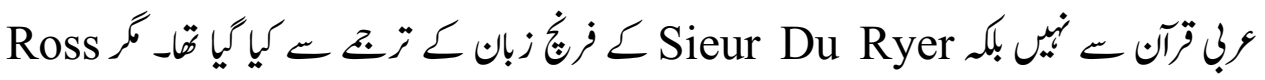
ن A Alexander

"Alcoran of Mohomet, Translated out of Arabic for Satisfaction

of All that desire to looking into Turkish Vanities"

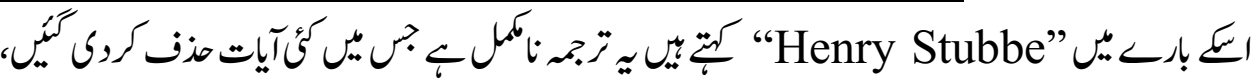

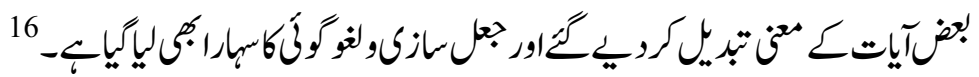

${ }^{14}$ John Daven-Port, An Apology for Mohammed and Quran, Darut-Tablighe Islami, Ghum, Iran, p.13.

${ }^{15}$ Lodvico Maracius was a Latin Translator of Quran who released the Latin Quran Translation in Padowa. This translations contained Original Text and Explanatory Notes and was a good effort from him.

${ }^{16}$ Henry Stubbe, An Ancount of the Rise and Progress of Mahometanism with the life of Mahomet, ed. Hafiz Mahmud Khan Shirani, Lahore, Sheikh Muhammad Ashraf, 1954-1959. 
6George Sales

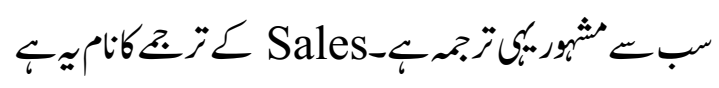

The Koran; or Alcoran of Mohammed with explanatory notes and Preliminary discourse.

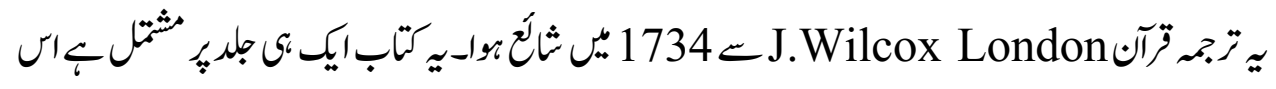

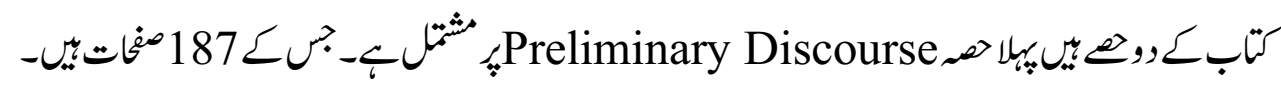

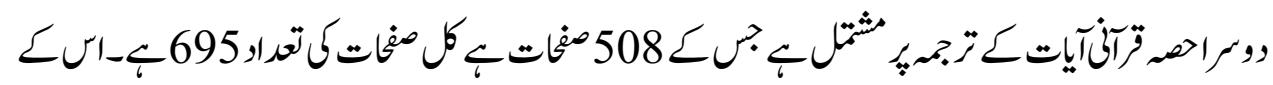

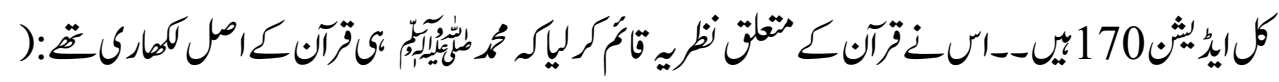

"Muhammad was really the author and chief contriver of the Koran in beyond dispute" 17

\section{Edward Henery Palmer} Edward Hennery Palmer (The Quran)

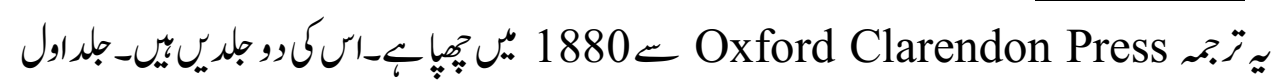

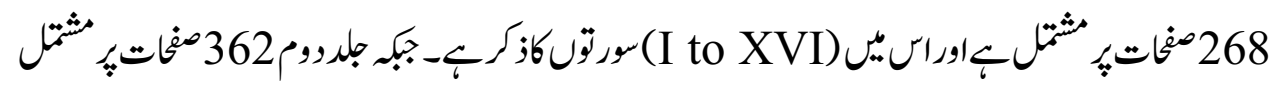

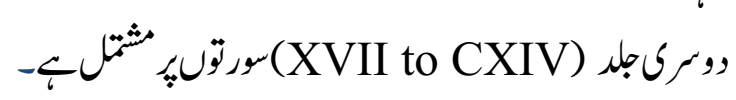

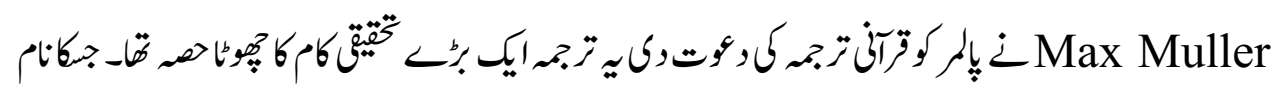
"The Sacred books of East Series”

\footnotetext{
${ }^{17}$ George Sale, The Koran, Fredrick Worn and Company, new York, 1890, p.50,
} 


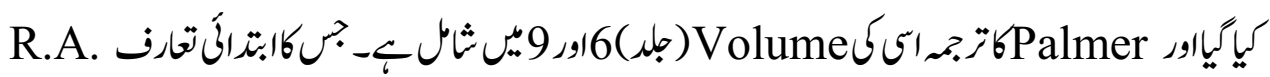

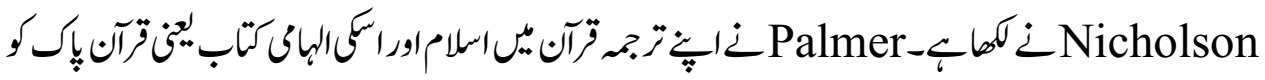

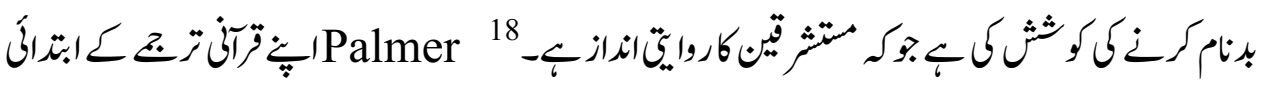

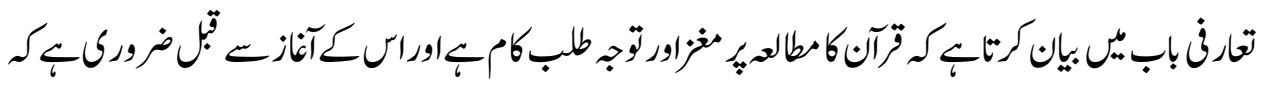

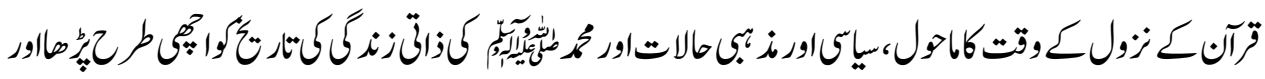

\section{GJohn Meadows Rodwell}

Sohn Meadows Rodwell

The Koran: Translated from the Arabic, The Surahs arranged in

chronological order with notes and index.

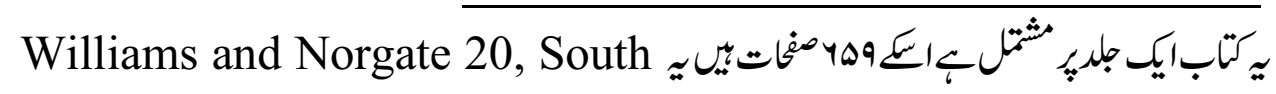
Frederick Street Edinbargh

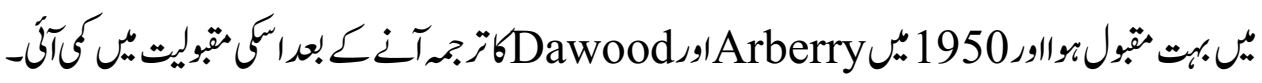

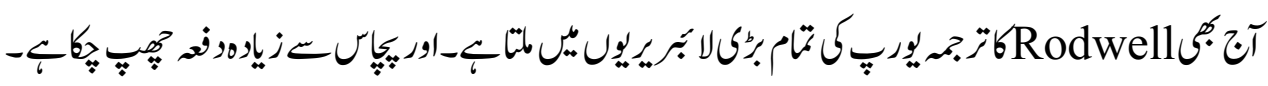
ائكتاب Milman ${ }^{20}$

This book is not only laborious but also candid and comprehensive $^{21}$

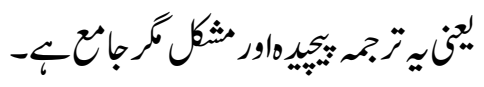

\footnotetext{
${ }^{18}$ E.H ,Palmer, The Quran, Oxford clarendon press ,1880,p.ixxvi

${ }^{19}$ E.H ,Palmer, The Quran, Oxford clarendon press ,1880,p.ixxvi

${ }^{20}$ Rodwell ,M.A, EL KORAN; The Quran translated from the Arabic, The surahs arranged in cholonogical order with notes and index,Second Edition ,Bernard Quaritch,London, 1876, preface

${ }^{21}$ Milman, D.D., Henery Hart, History of latin CHRISTINITY, Vol,ii. John Murry ,Albemarle street 1872, London.p:167
} 


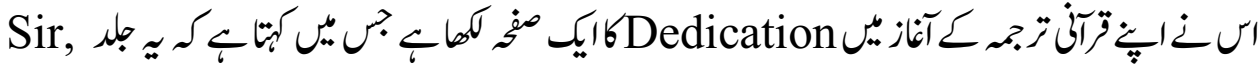

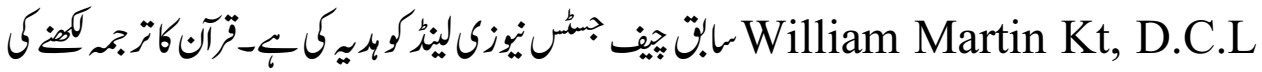

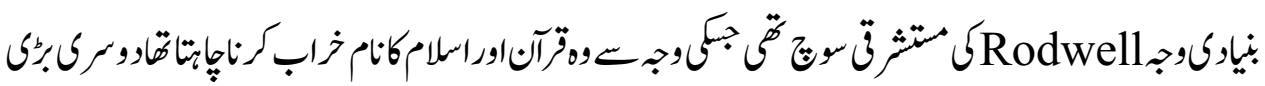

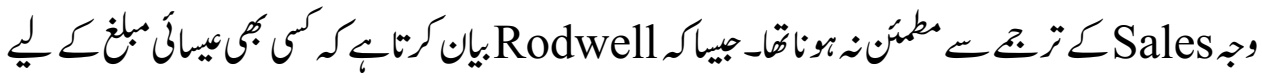

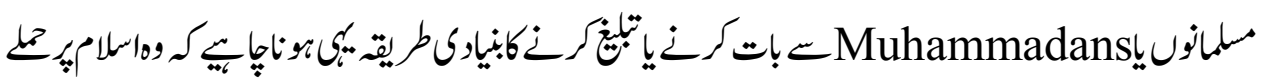

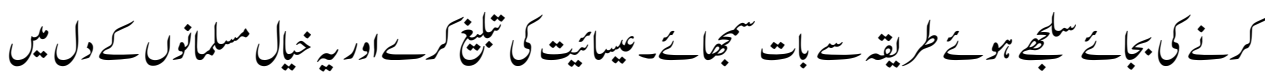

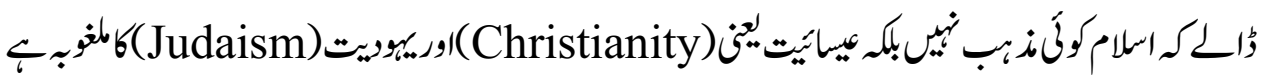

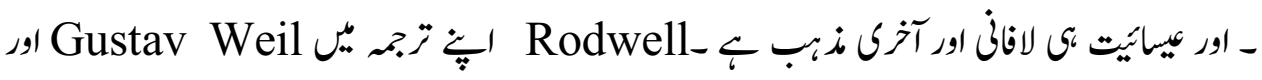
ك Theodore Noeldeke

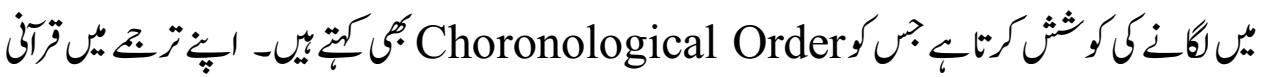

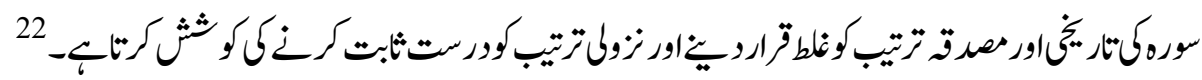
Richard Bell عichard Bell

The Quran Translated With a critical re-arrangement of the surahs

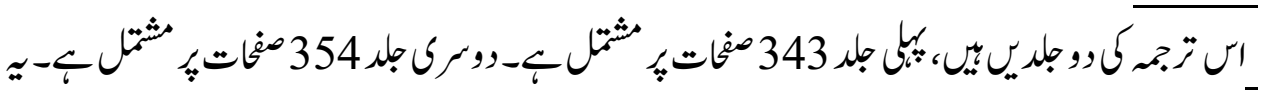
然 Edinburgh, Uk, T. \& T. Clark, 38 George Street

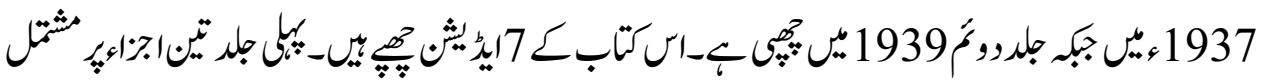
(i)Preface
(ii) Bibliography
(iii) Surahs

\footnotetext{
22 A.J Arberry, The Koran Interpreted, George Allen and Unwin ltd, London ,first published in 1955,preface,p. 18

${ }_{23}$ Bell Richard,THE QURAN ,Translated with a critical rearrangements of Surrahs ,T and T Clark ,Edinburgh ,1937,Vol. 1
} 


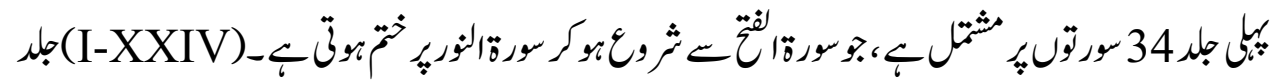

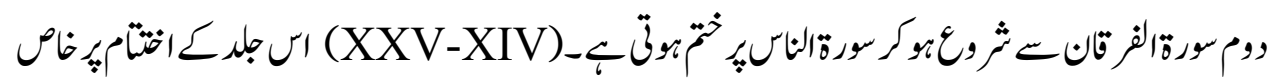

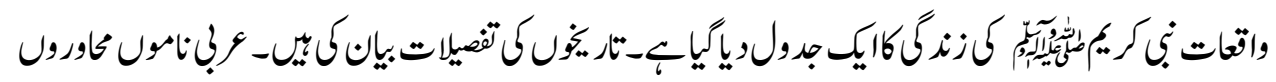

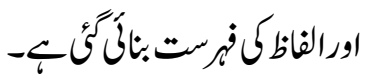
Bell

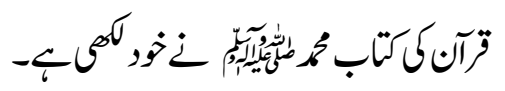

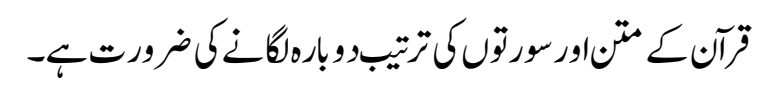

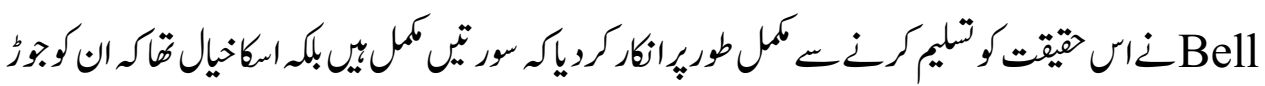

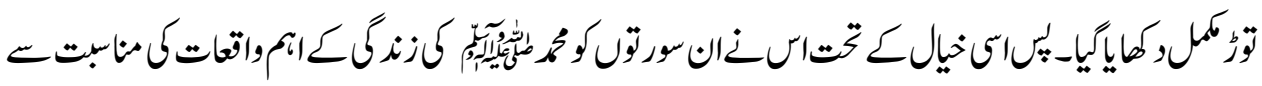

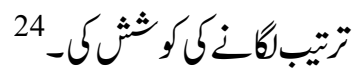

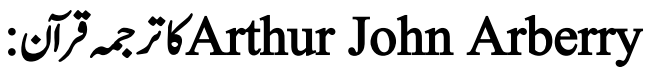
EArthur John Arberry

The Koran Interpreted

GArberry

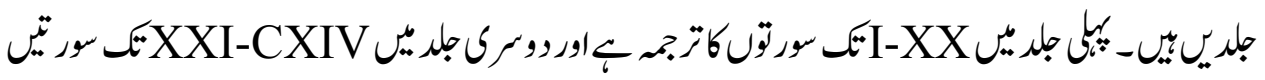

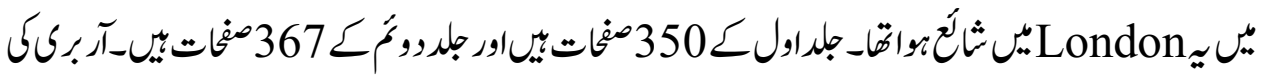

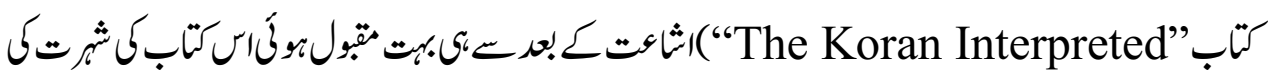

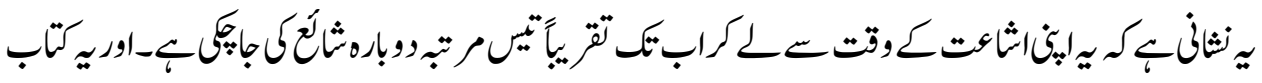

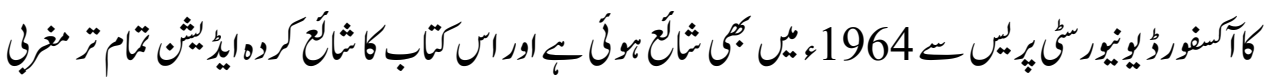

\footnotetext{
${ }^{24}$ Bell Richard,THE QURAN ,Translated with a critical rearrangements of Surrahs ,T and T Clark ,Edinburgh ,1937,Vol. 1
} 


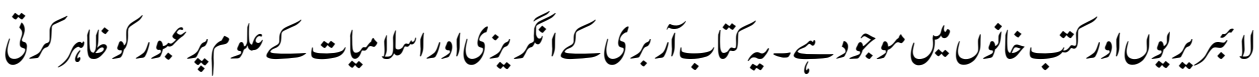

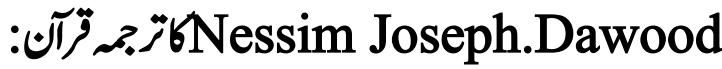

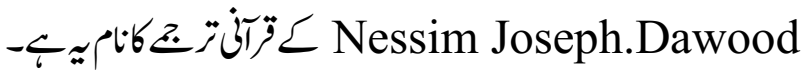
The Koran (A New Translation )

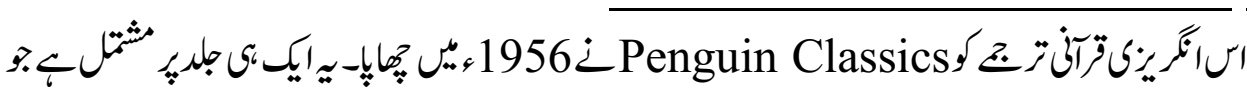

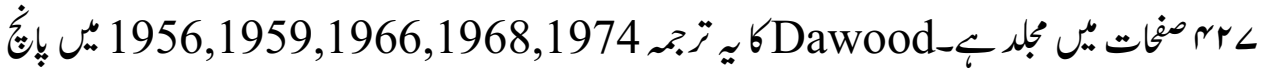

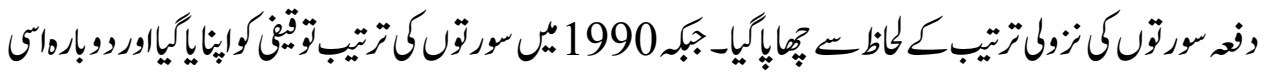

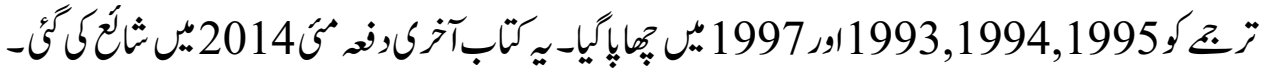

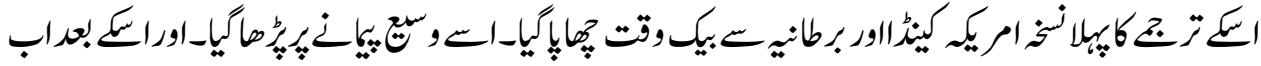

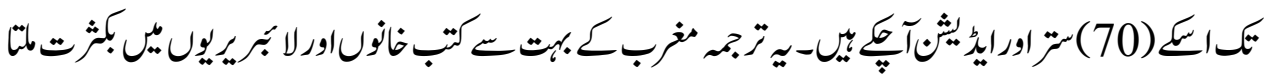

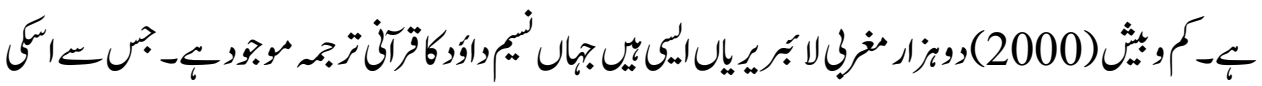

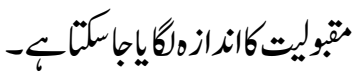

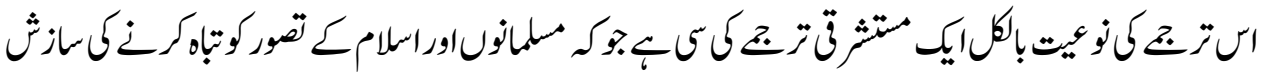

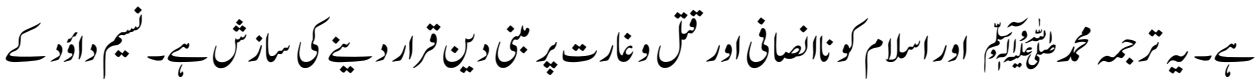

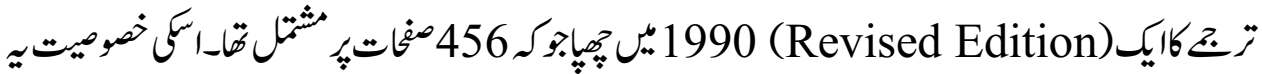

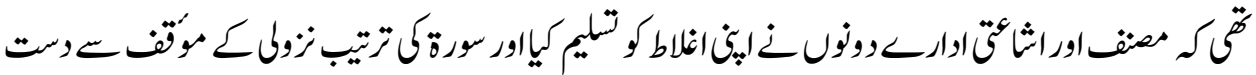

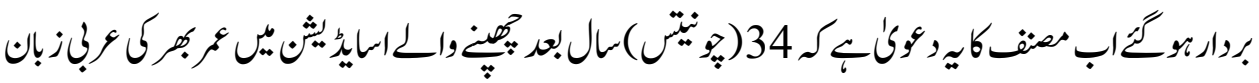

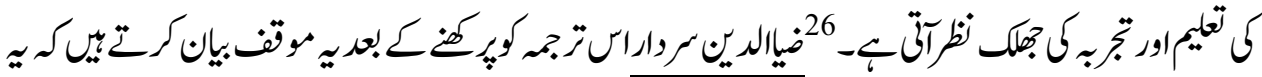

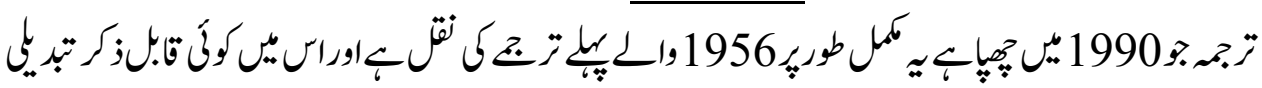

25 Arrbery A.J., The Koran interpreted, oxford university press UK,1964 Introduction p:ix

${ }^{26}$ Dawood, N.J, IBN KHALDUN, An intrduction to history, Princeton University Press. 1967, 


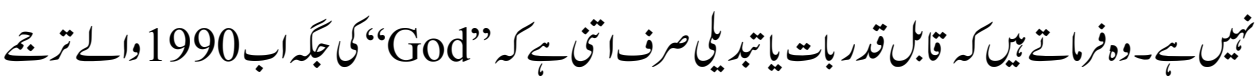

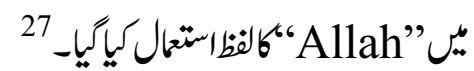

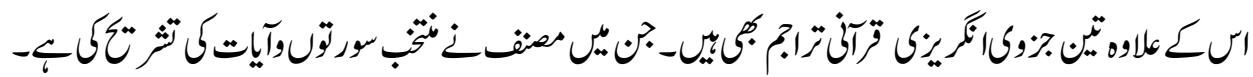

\section{Alen Jones}

EAlen Jones

The Quran

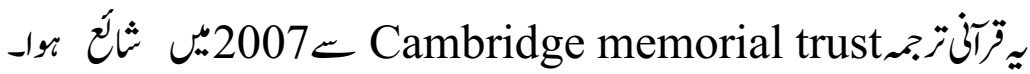

Alen Jones

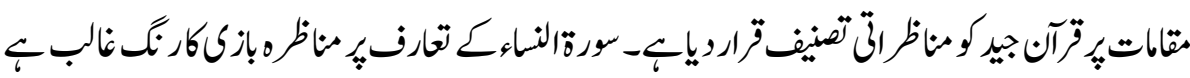

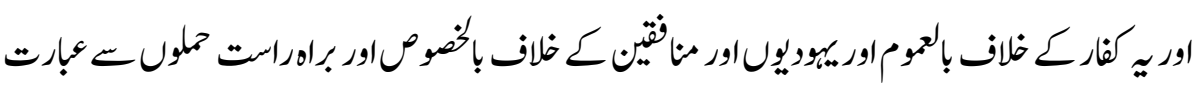

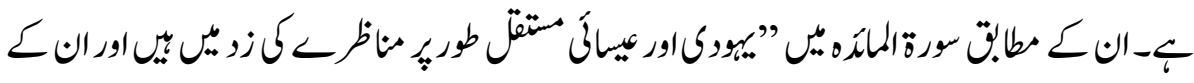

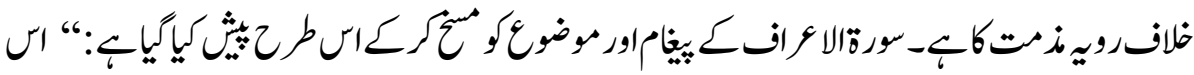

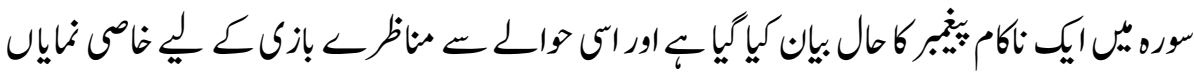

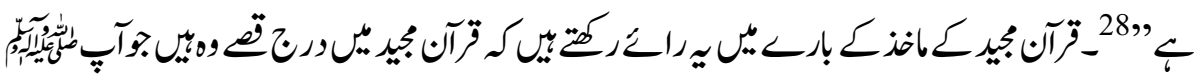

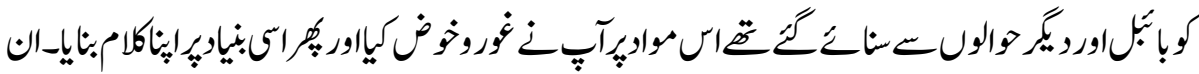

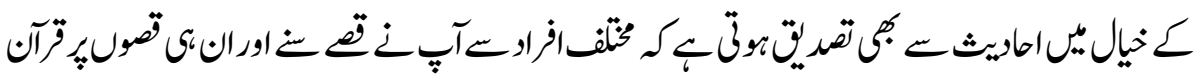

\section{T6homas Cleary}

${ }^{27}$ Ziauddin Sardar, Reading the Quran the contemporary Relevance of the Scared text of Islam, Oxford University press 2001, New York, Gerald MacLean, Britain and the Muslim World; Historical Perspectives, Cambridge Scholars publishing, 2011 P: 193-199.

28 Akthar Al-Wassy, Prof, Mustashreqeen Aur Angrezi Tarajum-e-Quran, Prof.Waheed- Ur-Raheem Qudwai ky Mazameen, Naveed Hafeez Press, Lhr, P.22. 


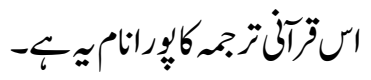

"The Essential Koran"

"The Heart of Islam"

An introductory selection of reading from Qur'an

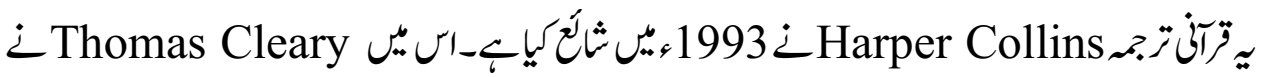

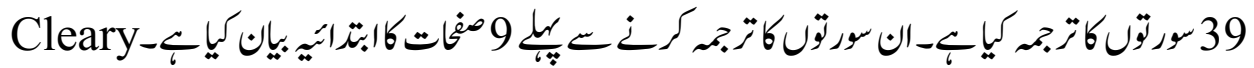

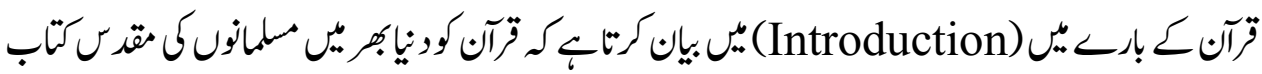

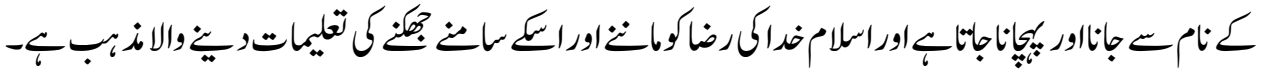

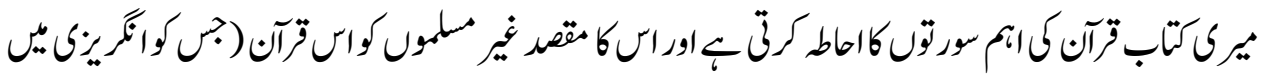
Koran

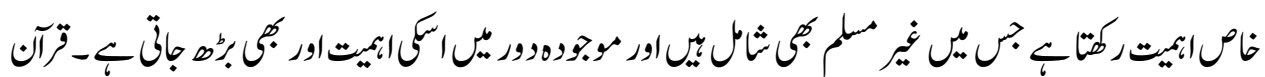

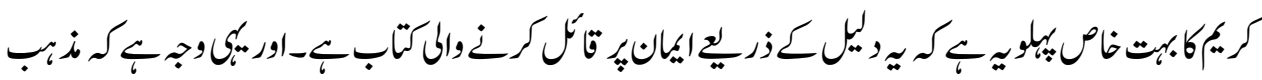

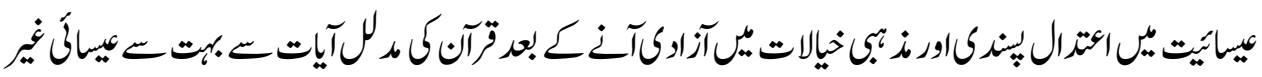

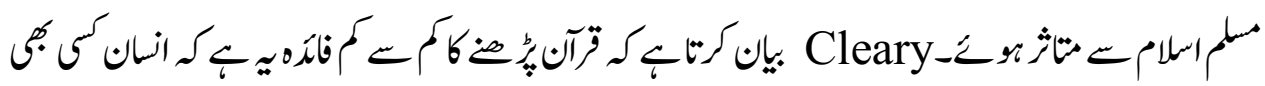

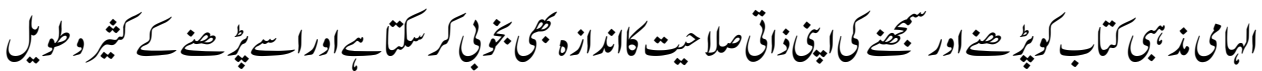

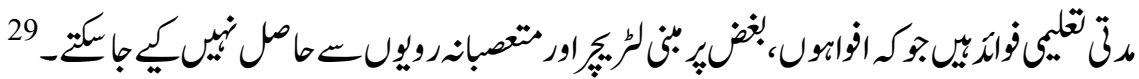

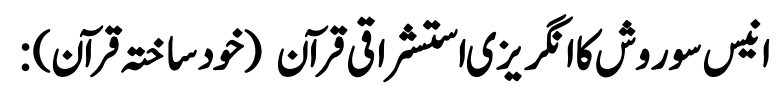

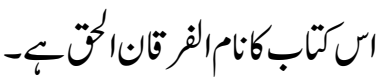

The True Furqan

إن6جزاول Project OMEGA — America

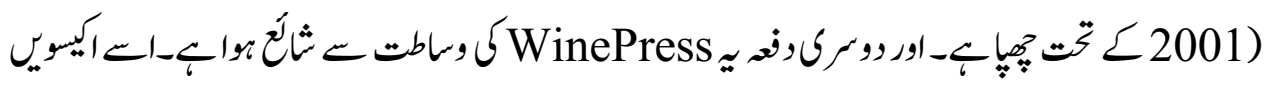

\footnotetext{
${ }^{29}$ Thomas Cleary, The Essential Koran "The Heart of Islam" an Introductory selection of reading from the Quran. Harper Collins Publishors, New York, p.X.
} 


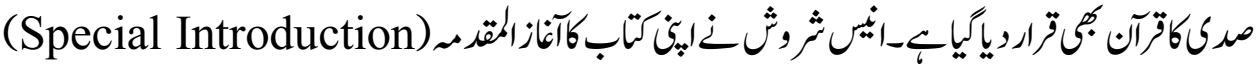

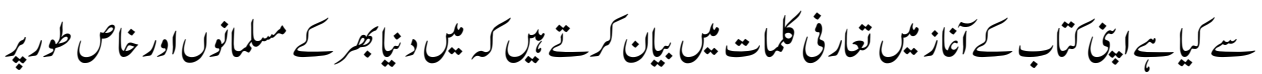

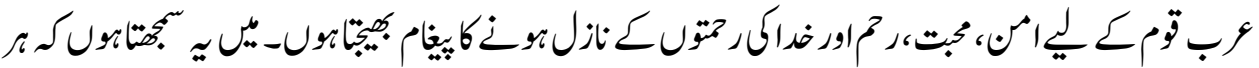

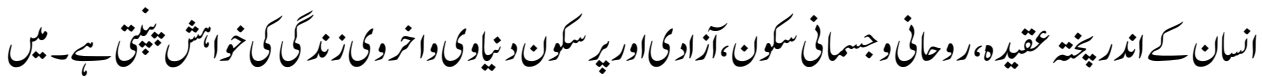

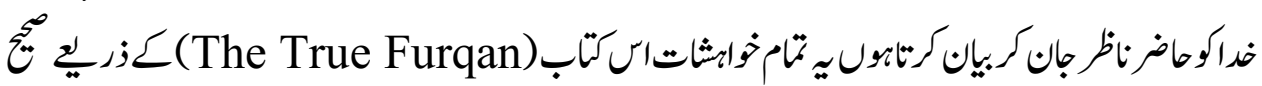

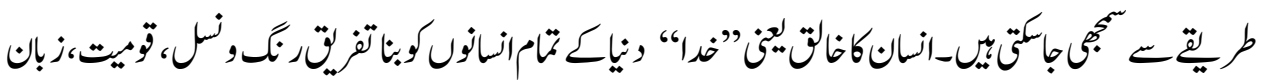

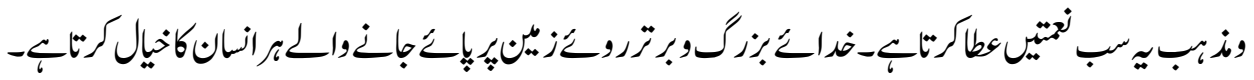

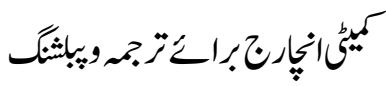

"Al-Safee and Al Mahdy" "الصاقُوالمهبى"

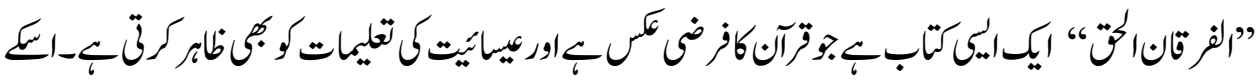

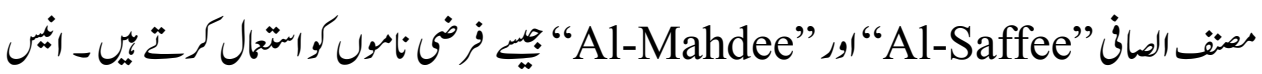

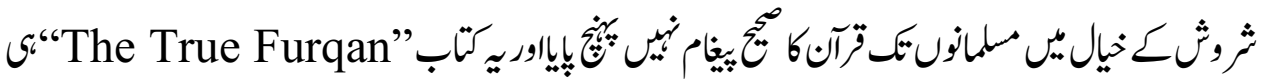

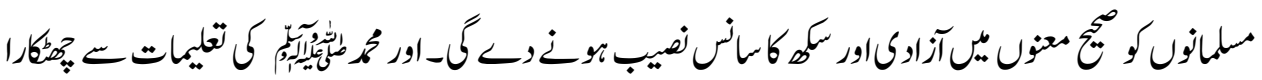

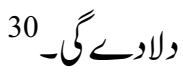

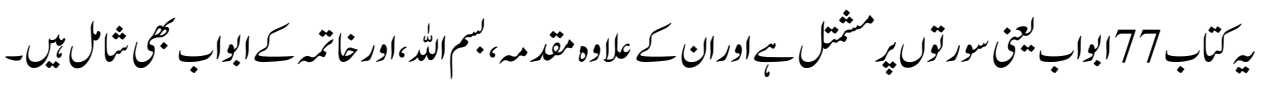

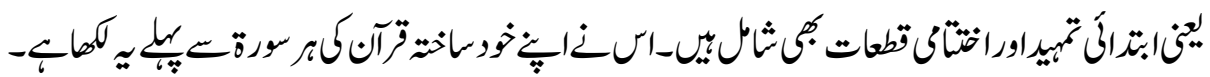

In the name of the Father, the word, the Holy spirit, the one and only true $\operatorname{God}^{31}$

\footnotetext{
${ }^{30}$ En.wikipedia.org/wiki/the-true-Furqan

${ }^{31}$ Al-Furqan Al-Haq, Al-Mehdi WalSafi, Wine Press Publishing,2001,Surah AlBismillah.
} 


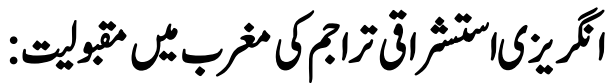

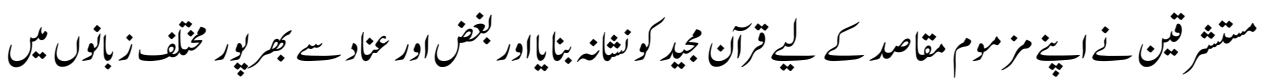

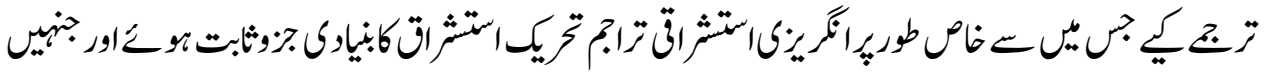

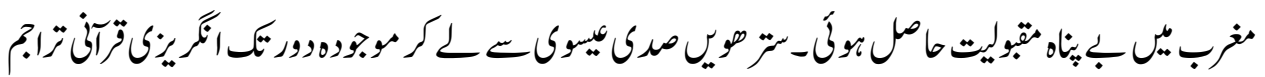

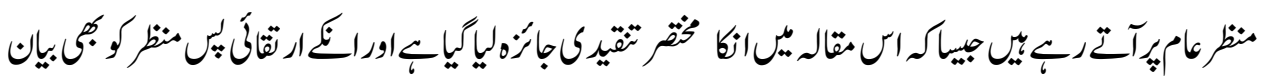

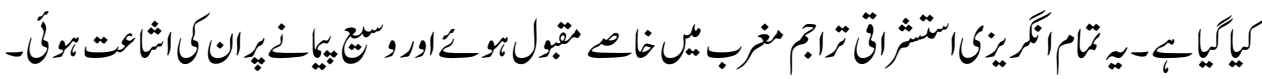

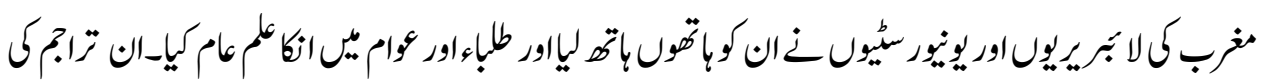

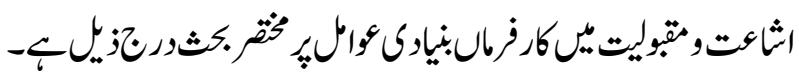

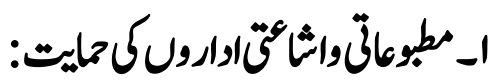

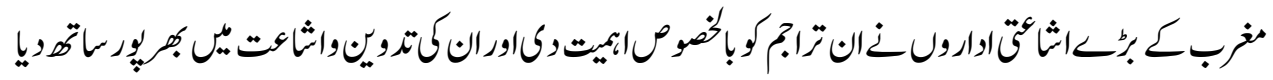

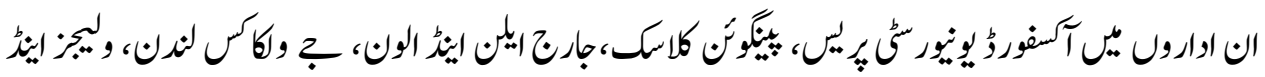

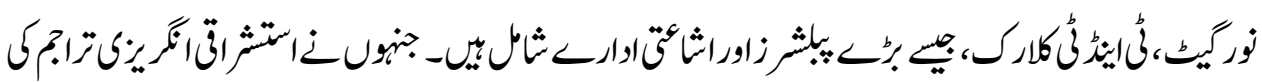

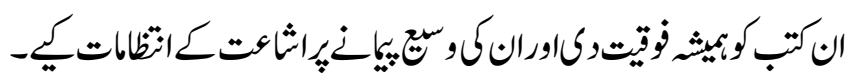

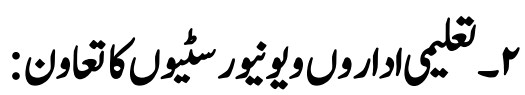

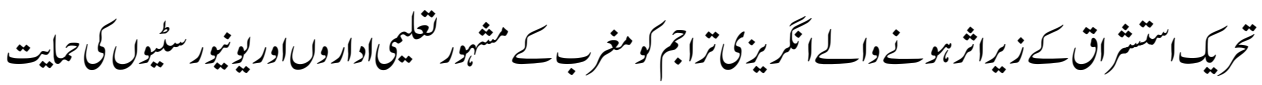

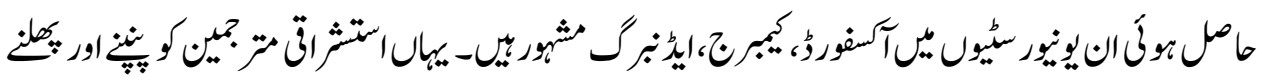

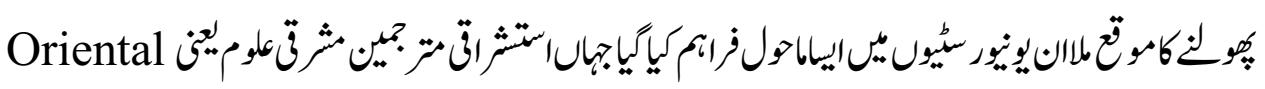
ين تبر كtudies

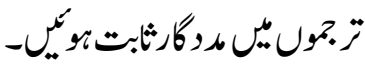

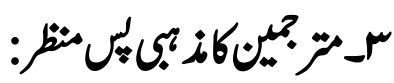

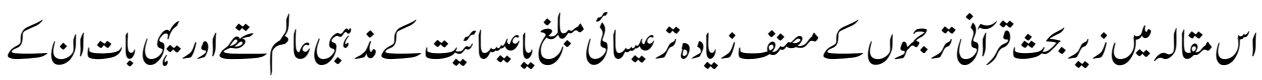

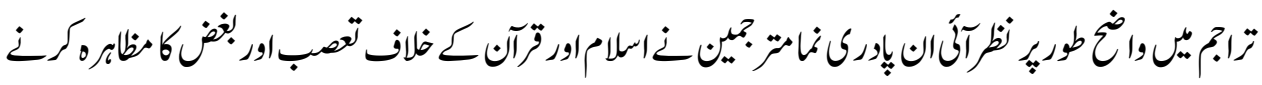




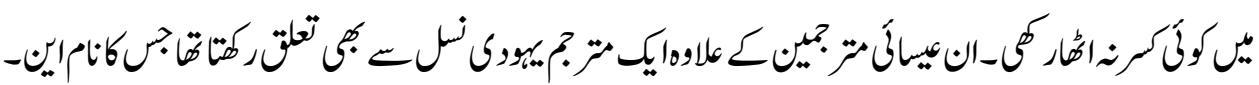

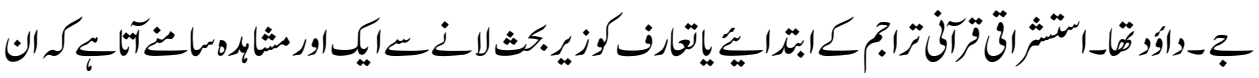

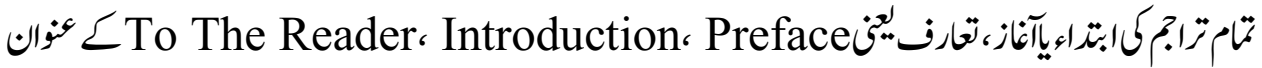

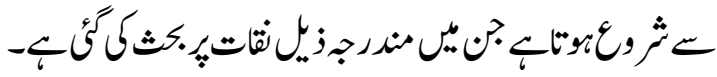

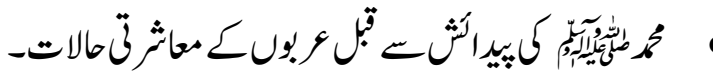

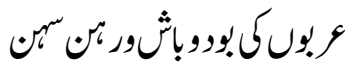

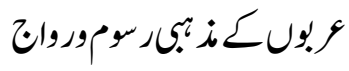

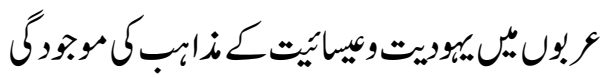

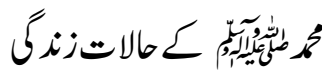

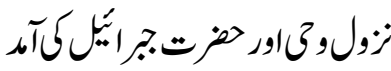

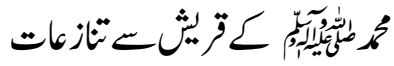

$$
\begin{aligned}
& \text { كمويرناراور }
\end{aligned}
$$

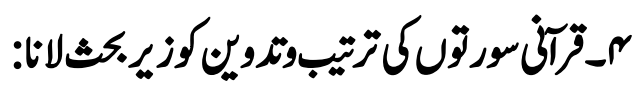

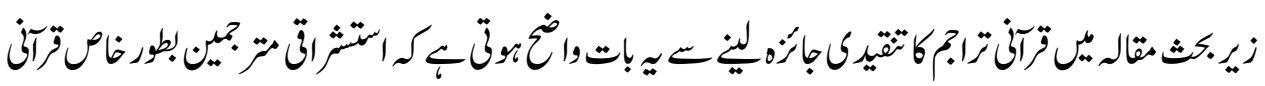

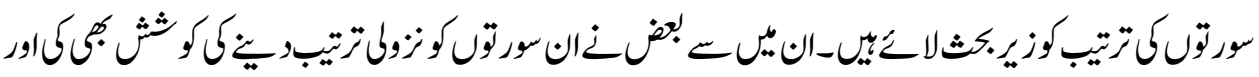

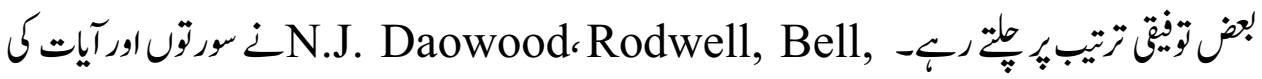

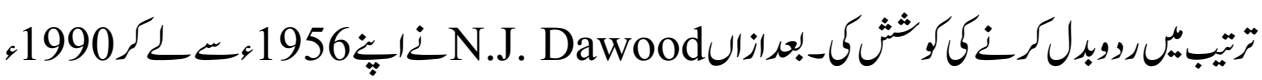

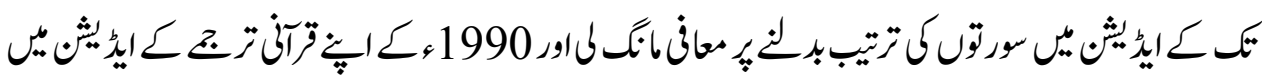

${ }^{32}$ Palmer Edward, Hennery THE QURAN, F.X Muller, ,Clarendon Press ,Oxford, 1880, Vol.1,INTRODUCTION,P.liii 


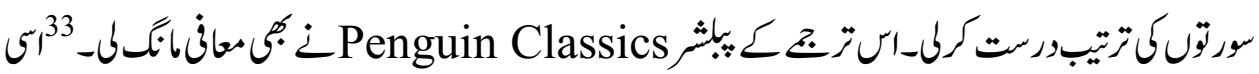

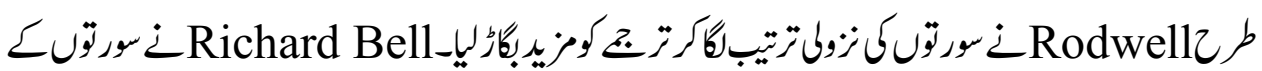

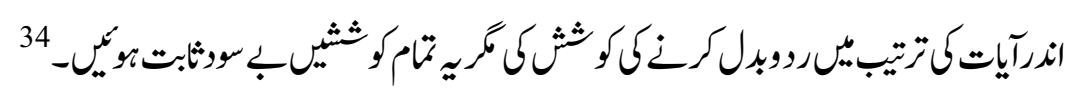

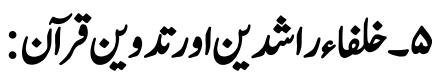

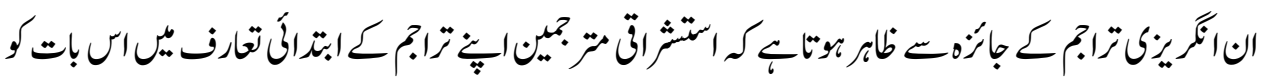

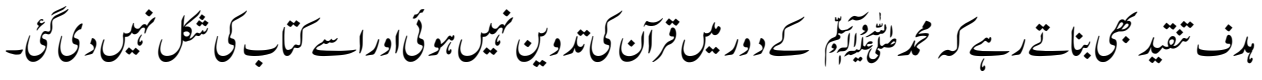

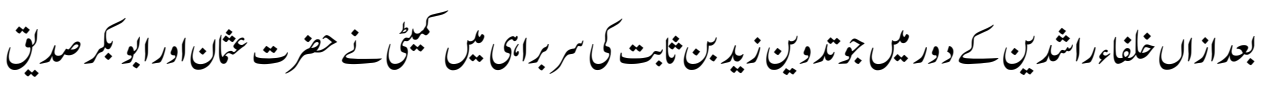

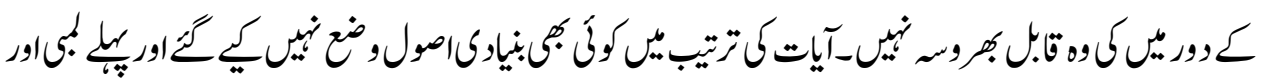

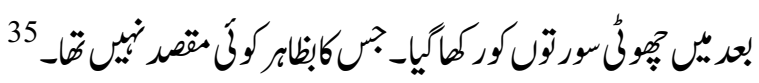

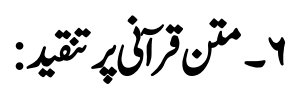

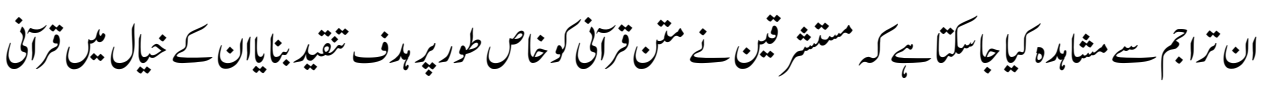

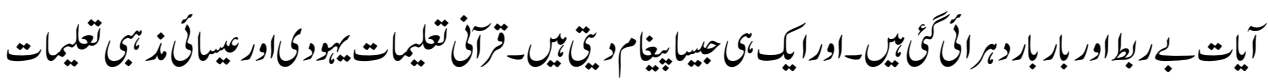

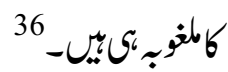

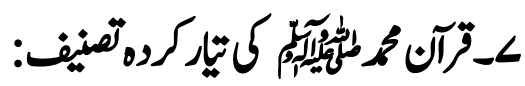

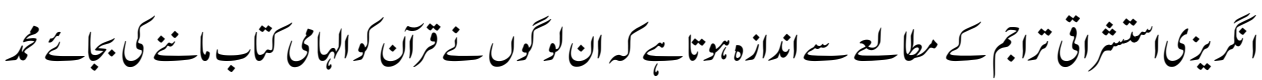

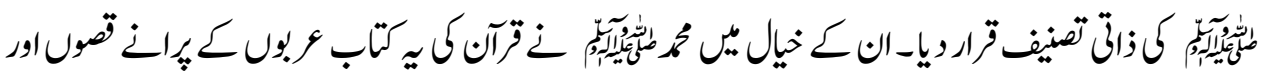

${ }^{33}$ Dawood .N.J, The Koran, penguin books, London 1956,p.12

34 Alfred Guillaume, Review on the Koran Interpreted, Muslim World 47:1( 1957),248(He was British Arabist Scholar of Islam and Hebrew Bible /Old Testament scholar).

${ }^{35}$ Merril, John, E, "Dr Bell critical analysis of the Quran", Muslim World 37:2,(1947),134-148

${ }^{36}$ Rodwell ,M.A, EL KORAN; The Quran translated from the Arabic, The surah's arranged in chronological order with notes and index, Second Edition ,Bernard Quaritch ,London, 1876, preface,p.7 


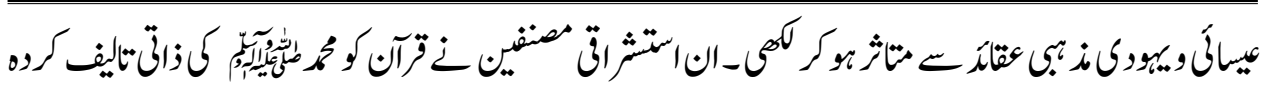

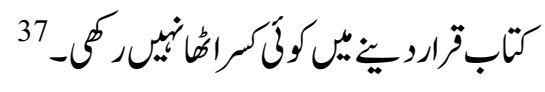

1-فرمت موره:

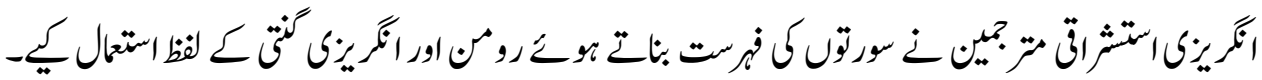

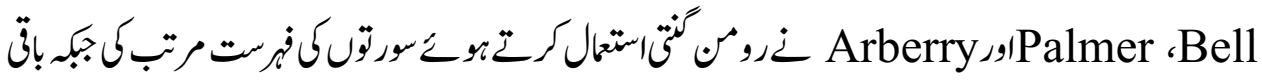

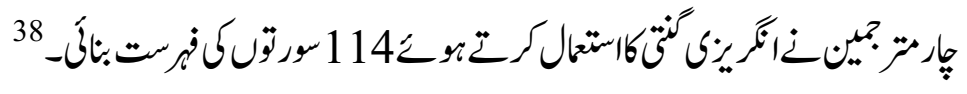

9-نام سوره تصحرادآيات:

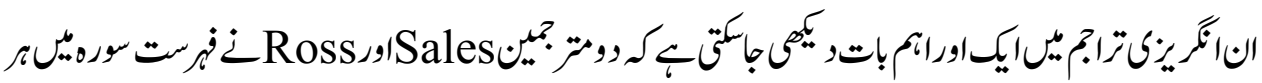

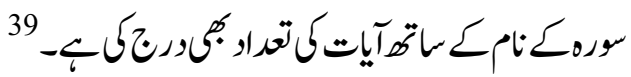

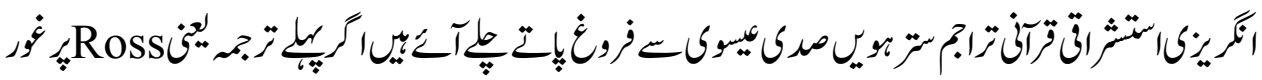

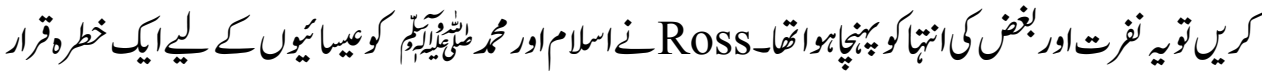

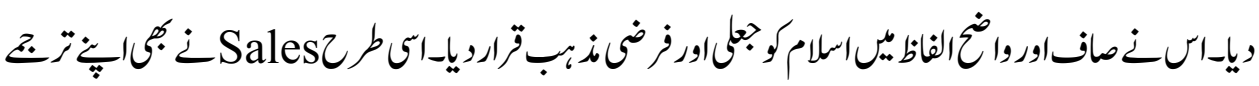

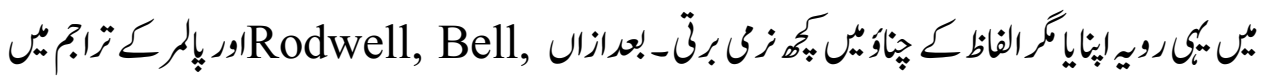

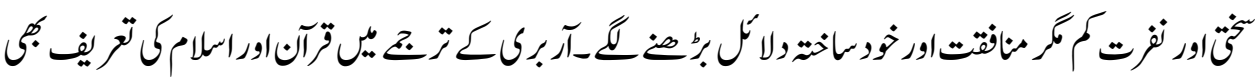

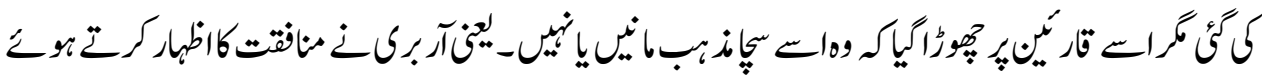

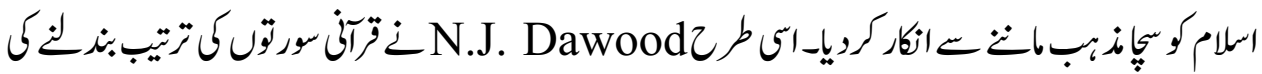

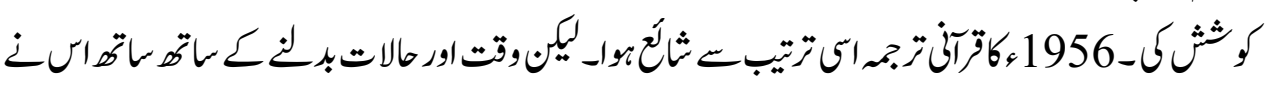

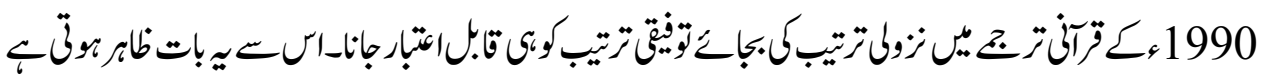

${ }^{37}$ Bell Richard, THE QURAN ,Translated with a critical rearrangements of Surah's ,T and T Clark,Edinburgh ,1937,VOL.1, preface, p.vi

${ }^{38}$ Arthur j. Arberry, The Koran Interpreted, Oxford University Press, new York 1964,preface,p.ix

${ }^{39}$ George Sales, The Koran, London, Fredrick Warne, 1734, p.VII. 


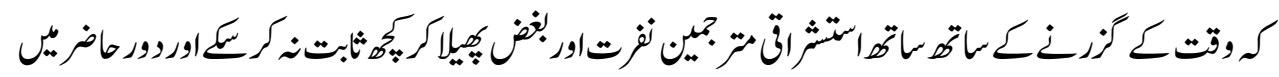

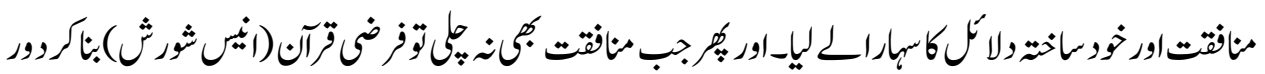

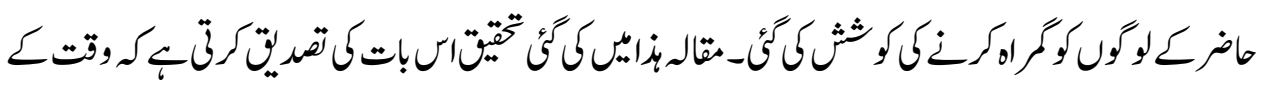

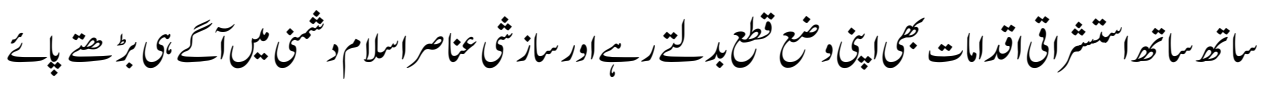

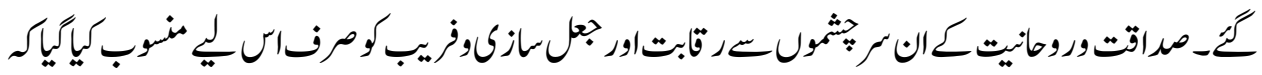

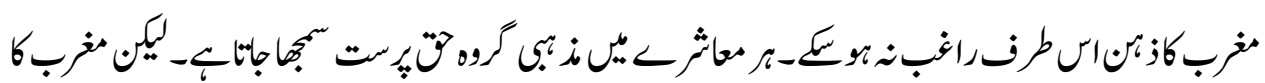

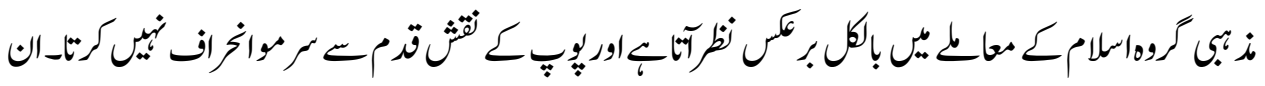

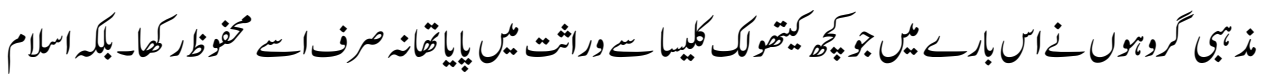

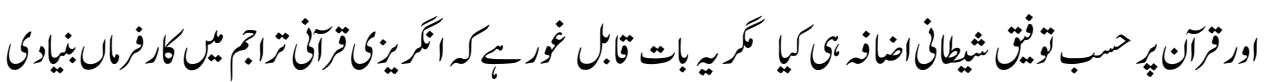

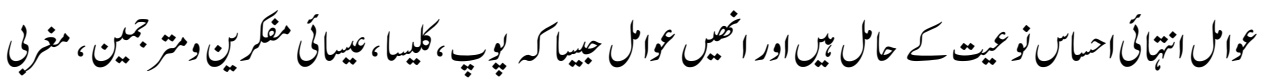

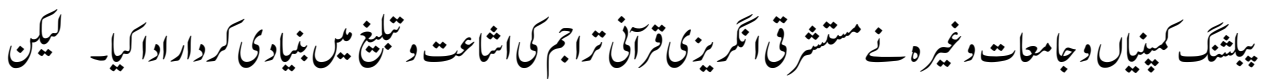

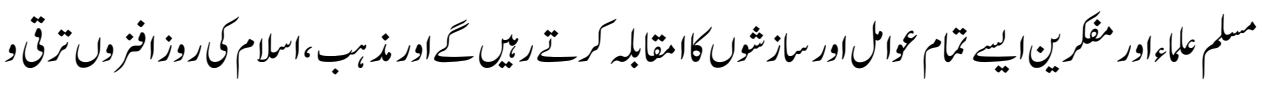

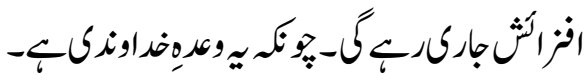

\section{(c) () ()}

Attribution-NonCommercial-ShareAlike 4.0 International (CC BY-NC-SA 4.0) 